tion: in the global competitive market, Germany can further enhance its profile by consistently pursuing its partnershipbased approach. This would mean that the country deliberately sets itself apart from the mainstream of recruiting international students to cover deficits in university budgets. There is plenty of evidence that not only universities, but also the economy and society, reap long-term benefits. German universities are therefore doing well to further internationalize their structures and offer attractive conditions to students, researchers, and experts from all over the world. Attractiveness not only depends on the legal framework for studying, research, and employment, but also on the establishment of a cosmopolitan culture within universities and beyond. The argument does not extend, however, to posit that students-including international students-should be exempt from making a financial contribution to the costs of their degree. For a long time, the German Rectors' Conference has expressed its support for the introduction of moderate, socially supported tuition fees for all students.

It remains to be seen how the situation will evolve further. The newly elected state government in North Rhine-Westphalia, Germany's most populous state, has announced its intention to introduce tuition fees for students from countries outside the European Union. It is not yet clear exactly how this will work, whether other federal states will follow suit, or what impact this will have on the higher education sector's internationalization efforts. But what is already clear is that universities will only be able to pursue a clear internationalization strategy if they are given greater scope for autonomous decision-making in international matters-from admissions and staff recruitment to resource allocation.

DOI: http://dx.doi.org/ıo.6oI7/ihe.20I8.92.I02I3

\section{Mapping Internationaliza- tion on US Campuses}

\section{Lucia Brajkovic and Robin Matross Helms}

Lucia Brajkovic is senior research specialist, and Robin Matross Helms is director for internationalization and global engagement, American Council on Education.E-mails: Ibrajkovic@acenet.edu and rmhelms@ acenet.edu.

A signature research project of the American Council on Education's (ACE) Center for Internationalization and Global Engagement (CIGE), the Mapping Internationalization on U.S. Campuses study, assesses every five years the current state of internationalization at American colleges and universities, analyzes progress and trends over time, and identifies future priorities. The 2016 Mapping surveylike the three previous iterations-addressed the six key areas that comprise the CIGE Model for Comprehensive Internationalization: articulated commitment; administrative structures and staffing; curriculum, cocurriculum, and learning outcomes; faculty policies and practices; student mobility; and collaboration and partnerships. This article is based on a longer report, which is available at www.acenet. edu/mapping.

\section{Key findings fROM THE 2016 MaPPING SURVEY}

As in $201 \mathrm{I}$ and previous iterations of the study, the final picture painted by the 2016 Mapping data is of a complex landscape-promising gains in many areas, slower (or negligible) progress in others, and some noteworthy shifts in broader trends and priorities. The past five years have generally seen greater institutional support for internationalization, in terms of both administrative structures and staffing, and financial resources. Articulated commitment to internationalization in mission statements and strategic plans is more prevalent, and is increasingly supported by specific policies and programming that operationalize broad ideals. Two-year institutions, in particular, have seen notable progress in a number of areas, whereas doctoral institutions seem to have plateaued in certain aspects of internationalization.

While the data in the individual pillars of the CIGE Model for Comprehensive Internationalization are for the most part encouraging, a comparison of overall percentages across categories indicates that for many institutions, internationalization efforts are still focused first and foremost on the external; student mobility in both directions and international partnerships are identified as top priorities for internationalization. On-campus internationalization efforts, in contrast, are seen as relatively less important; internationalization of the curriculum/cocurriculum and faculty professional development rank number four and number five, respectively, in terms of overall priorities for internationalization. Though 2016 saw progress in terms of student learning outcomes and academic requirements, still only about half of institutions reported active efforts toward curriculum internationalization. When it comes to faculty policies and support, progress over time has been markedly slower than in many other areas, and recognition of faculty contributions to internationalization is a concern going forward.

This external orientation for internationalization efforts is ultimately problematic in that it neglects the core of the academic enterprise. At its heart, higher education is about student learning, and for the majority of US students 
who are not internationally mobile-as well as international students coming to US institutions from around the world - that means the on-campus curriculum and cocurriculum. As the primary drivers of teaching and research, faculty are the lynchpins of student learning; in order for students to achieve global learning goals, faculty must be globally competent themselves, able to convey their international experience and expertise in the classroom, well prepared to engage effectively with international students, and actively committed to the internationalization endeavor.

It is not an accident that "curriculum, cocurriculum, and student learning outcomes," and "faculty policies and practices" are the two center pillars of the CIGE Model for Comprehensive Internationalization. Their position is indicative of their importance; attention to these areas is critical in order for internationalization to fully take hold throughout colleges and universities, rather than remaining a peripheral activity. As core activities, they are arguably the hardest to change; going forward, however, they require increased effort and resources as institutions strive for deeper, more comprehensive campus internationalization.

The past five years have generally seen greater institutional support for internationalization, in terms of both administrative structures and staffing, and financial resources.

\section{The Future of Internationalization In the United STATES}

When looking toward the future of internationalization, it is impossible to ignore US political developments in early 20I7. The Mapping survey closed in December 2016, following the election of President Donald Trump, but prior to his inauguration. As of the writing of this article, the Trump administration has issued a series of executive orders and policy statements related to immigration and foreign relations that will likely impact, perhaps dramatically, student mobility-the aspect of internationalization delineated clearly by the data as the top priority for US colleges and universities.

In a letter to the secretary of the Department of Homeland Security sent by ACE and 46 other US higher education associations in response to the January 2017 executive order titled "Protecting the Nation from Foreign Terrorist Entry into the United States," ACE's president, Molly Corbett Broad, stated, "We fear the chilling effect this will have on the ability of international students and scholars to continue to see the United States as a welcoming place for study and research." This "chilling effect" was also a central component of the court arguments that ultimately stayed the initial executive order.

While anecdotal reports from US campuses, as well as sources abroad, indicate that the current political environment is indeed factoring into international students' decisions about where to study, the long-term effect on student mobility numbers-and broader internationalization efforts-is difficult to predict. Responses will undoubtedly vary by institution and sector.

At a recent meeting of the current cohort of ACE's Internationalization Laboratory, an I8-month program that guides institutions through a strategic planning process for internationalization, some participants described the overall climate for internationalization as "demoralizing"; others, however, characterized it as "energizing" - a time to refocus and push forward. In light of new policy hurdles and a charged political climate, some colleges and universities may indeed turn away from internationalization activities. For others, though, momentum will continue, perhaps with different activities and emphases coming to the fore.

Rather than relying on direct recruitment of international students, for example, some institutions might seek to strengthen relationships with international partners as a means to facilitate student mobility. Others may develop new academic programming for overseas student populations, or enhance their capacity for virtual teaching and research collaborations. And some institutions may turn their internationalization focus inward, with increased attention and resources devoted to on-campus curricular, cocurricular, and faculty development initiatives-exactly what is needed, as noted previously, to advance progress toward comprehensive internationalization in ways that an exclusively external orientation will not allow.

Whatever happens in terms of politics and policy, the overall lesson from the Mapping study will likely endure: there are always challenges to internationalization, but there are always opportunities as well. Only time-and the 202I Mapping Internationalization on U.S. Campuses survey-will tell what impact the current political discourse will have, and how the internationalization journey will play out on American college and university campuses in the coming years.

DOI: http://dx.doi.org/Io.6oI7/ihe.20I8.92.I02I4 